\title{
Antimicrobial Resistance Genes of E. coli Isolated from Broiler Chickens in Upper Egypt
}

\author{
Hassan Ahmed Khalaf ${ }^{1, ~ *, ~ B a d r y ~ A m l ~}{ }^{2}$, Abdelhafez Awd ${ }^{1}$ \\ ${ }^{1}$ Department of Poultry and Rabbit Diseases, Faculty of Veterinary Medicine, Assiut University, Assiut, Egypt \\ ${ }^{2}$ Faculty of Veterinary Medicine, South Valley University, Qena, Egypt
}

Email address:

a.hassan@aun.edu.eg(H. A. Khalaf), khalaf_poultry@yahoo.com (H. A. Khalaf)

${ }^{*}$ Corresponding author

\section{To cite this article:}

Hassan Ahmed Khalaf, Badry Aml, Abdelhafez Awd. Antimicrobial Resistance Genes of E. coli Isolated from Broiler Chickens in Upper Egypt. Animal and Veterinary Sciences. Vol. 9, No. 1, 2020, pp. 19-28. doi: 10.11648/j.avs.20200801.13

Received: December 27, 2019; Accepted: January 17, 2020; Published: March 6, 2020

\begin{abstract}
The background: $E$. coli infection is a septicemic disease with an economic importance of poultry causing multiple lesions in broiler chickens. Recent reports described increased resistance of $E$. coli to many antimicrobial agents. This research work aimed to detect, identify and study antimicrobial resistance genes of $E$. coli isolated from broiler chickens in Upper Egypt. Methods: Three-hundreds samples, including 200 liver and 100 tracheal swabs, were collected from broiler chicken flocks at different localities in Assiut and El-Minya Governorates. Samples were subjected to isolation and phenotypic identification, serological typing, detection of sensitivity and resistance to antimicrobial drugs and determination of genes responsible for resistance to antimicrobial agents. Results and conclusion: revealed that $E$. coli could be isolated and phenotypically identified with a percent ratio $70 \%$ (210 from 300). Twenty-six out of $30 \mathrm{E}$. coli isolates were serologically identified. Determination of antimicrobial susceptibility and resistance patterns of $E$. coli isolates to variable antimicrobial drugs using standard disk diffusion and minimum inhibitory concentration (MIC) methods was done. Detection of antimicrobial resistance genes of 12 serologically identified $E$. coli isolates showed that $f$ loR gene (Florfenicol resistance gene) was detected in 6 isolates and strA-strB gene was detected in 5 isolates, while aadA gene was detected in all 12 isolates. Both strA-strB and aadA are streptomycin resistance genes.
\end{abstract}

Keywords: E. coli, Antimicrobial Resistance, Resistance Genes, Disk Diffusion, MIC, Broiler Chickens

\section{Introduction}

Colibacillosis is a systemic disease of poultry caused by avian pathogenic E. coli (APEC) [15] and characterized by septicemia with multiple organ lesions, typically pericarditis, air-sacculitis, perihepatitis, peritonitis, and other extraintestinal lesions. With the increased use of intensive housing, colibacillosis has become the predominant bacterial disease affecting the poultry industry [13], and one of the leading causes of economic loss in the poultry industry worldwide [15].

Approaches to control APEC infections in the poultry industry include improved hygienic methods, vaccination, use of competitive exclusion products, and the introduction of novel immunopotentiators however, each of these practices have had restricted success [55]. This has necessitated the use of antimicrobial chemotherapy to control outbreaks of colibacillosis, but modern reports have described increased resistance to those antimicrobial agents commonly used for treatment [85]. Such overuse or mistreatment leads to spreading of antimicrobial resistance among poultry flocks, and appearance of multiple drug resistance pathogens [65]. Today resistance to antimicrobial agents has become a major concern both for human health and in veterinary medicine [63]. Multi-resistant bacteria are often found in poultry meat [21, 34], so that chicken products are suspected to be a source of food borne pathogen and antimicrobial resistance bacteria for humans [9]. E. coli acquire antimicrobial resistance more rapidly than other bacteria. Thus, changes in the resistance of this species may provide a good indicator of resistance in potentially pathogenic bacteria [83]. Multi-drug resistant strains of $E$. coli are ever-present in both human and animal isolates in different parts of the world [8] and multiple drug resistant, nonpathogenic $E$. coli found in the intestine is maybe an important reservoir of resistance genes [74] and momentarily drug-resistant $E$. coli of animal origin may colonize the human 
intestine [62]. So, E. coli is a commensally intestinal bacterium that usually used to monitor resistance to therapeutically precious antimicrobials in poultry [42].

The aim of the present study is to isolate and identify E. coli from broiler chickens in Upper Egypt, to determine their susceptibility and resistance to antibacterial drugs and to detect antibacterial resistance genes in $E$. coli isolates.

\section{Materials and Methods}

\subsection{Samples Collection}

A total of 300 samples including, 200 liver samples from freshly dead birds and 100 tracheal swabs from sacrificed diseased broiler chickens, aged from 15 to 45 days old showing clinical signs of colibacillosis, were collected from different broiler flocks at different localities in Assuit and El- Minya Governorates. Samples were collected into sterile tubes containing nutrient broth and were transferred immediately to the laboratory in an icebox, where they subjected to bacteriological examination with special reference for $E$. coli. Sterilized swabs were used to collect tracheal samples from each bird and then immediately broken off into nutrient broth, 70 tracheal swabs were collected from Assuit and 30 swabs from El-Minya. Liver samples were directly collected into sterile containers, after surface sterilization using heated spatula a bacteriological loop was inserted into the depth of organ and then inoculated in nutrient broth, 130 samples were collected from Assuit and 70 samples were collected from El- Minya.

\subsection{Isolation}

Samples were inoculated into nutrient broth then incubated at $37^{\circ} \mathrm{C}$ for 24 hours. Sub-culturing was carried out on Eosin methylene blue agar and incubation at $37^{\circ} \mathrm{C}$ for 24 hours. The growth was examined for typical $E$. coli colonies.

\subsection{Phenotypic Identification}

To confirm the presence of E. coli on suspected isolates, Gram stained films [25], motility test, biochemical reactions, including indole test, methyl red test, Voges-Praskauer test, citrate utilization test, urease test, hydrogen sulphide production test, gelatin hydrolysis test, arginine dehydrolase, nitrate reduction test and fermentation of sugars tests [53] were used.

\subsection{Serological Identification of Suspected E. coli Isolates}

Thirty randomly selected phenotypically identified $E$. coli isolates were subjected to serological identification using rapid diagnostic E. coli antisera set (DENKA SEIKEN Co., Japan) for diagnosis of the Enteropathogenic types according to Kok et al., (1996) [51].

\subsection{Determination of Antibacterial Susceptibility and Resistance Patterns of E. coli Isolates}

Sensitivity of $E$. coli isolates to antibacterial agents was determined by two methods as the following:

\subsubsection{Standard Disk Diffusion Method}

Single colonies that produced on agar media were cultured into broth culture and incubated at $37{ }^{\circ} \mathrm{C}$ for 18 hours, about $2 \mathrm{ml}$ of this broth culture were transferred to inoculate the Muller Hinton agar by using sterile pasture pipette, then all excess fluids were removed with pipette and the plate was leaved to be dry. The antibiotic discs were applied at adequate spacing to the surface of plate with sterile forceps and the agar plate was incubated for 24 hours at $37^{\circ} \mathrm{C}$. Judgment of the test was done following incubation; the degree of sensitivity was estimated by measuring the visible and clear zone of inhibition produced by diffusion of the used antibacterial agent from the disc into surrounding medium. Interpretation of results was performed according to Quinn et al., (1994) [76] and koneman et al., (1997) [52].

\subsubsection{Determination of Antimicrobial Susceptibility and Resistance Patterns of E. coli Using MIC}

The MIC value is reported with interpretation guidelines that have been established by the Clinical and Laboratory Standards Institute (CLSI) formerly (National Committee for Clinical Laboratory Standards NCCLS, 2003a, b; CLSI, 2008; 2013) $[22,23,70,71]$.

Twelve E. coli isolates which were previously phenotypically and serologically identified, were incubated into nutrient broth and cultures were adjusted to be $10^{5}$ $\mathrm{CFU} / \mathrm{ml}$ [38]. The standard plate count method technique [16] was used to adjust the number of $E$. coli per milliliter in the inoculated nutrient broth.

The MIC value of colistin-sulphate, doxycycline, gentamicin, streptomycin, norfloxacin, ceftriaxone, florfenicol was determined. All antimicrobial agents were purchased from Sigma (Missouri, USA), except for norfloxacin, which was obtained from Bayer AG (Leverkusen, Germany).

MIC was carried out by broth micro-dilution method using micro-titer plates [43]. The antibiotic concentrations ranged from 0.25 to $256 \mu \mathrm{g} / \mathrm{ml}$. The MIC standard break-points for $E$. coli that have been established by the Clinical and Laboratory Standards Institute (CLSI) formerly (National Committee for Clinical Laboratory Standards NCCLS, 2003a, b; CLSI, 2008; 2013) $[22,23,70,71]$ were used.

\subsection{Detection of Antimicrobial Resistance Genes of E. coli Isolates}

Total bacterial DNA was extracted from twelve serologically identified E. coli isolates, according to Promega technical manual (Wizard Genomic DNA Purification kit). PCR was used for detection of resistance genes of $\mathrm{E}$. coli isolates including aadA and strA-strB genes for streptomycin and floR gene for florfenicol. The sequences of primers are shown in table 1 . The parameters for all reactions were described in the following profile; initial denaturation at $94^{\circ} \mathrm{C}$ for 4 minutes followed by 35 cycles of denaturation at $94^{\circ} \mathrm{C}$ for 45 seconds, annealing at $60^{\circ} \mathrm{C}$ for streptomycin genes and $58{ }^{\circ} \mathrm{C}$ for florfenicol gene for 30 seconds, and extension for 45 seconds at $72^{\circ} \mathrm{C}$. The final extension took 10 minutes at $72^{\circ} \mathrm{C}$. The PCR product (448bp) was seen by electrophoresis in a $1.5 \%$ agarose gel stained with ethidium bromide for visualization performed 
in a horizontal gel chamber plate. The running buffer was $0.5 \mathrm{X}$ TBE (Tris borate EDTA (pH 8.3). The $1 \mathrm{~kb}$ plus DNA ladder

was used as a reference standard molecular weight marker.

Table 1. Showing primers, their sequences, target genes, annealing temperatures and amplicon sizes (bp) applied for the detection of antimicrobial resistance genes in 12 strains of E. coli.

\begin{tabular}{|c|c|c|c|c|c|}
\hline Primers & Sequence (5'-3') & Target & Annealing Temp. & Amplicon Size (bp) & Reference \\
\hline \multicolumn{6}{|l|}{ Flourfenicol } \\
\hline StCM-F & CACGTTGAGCCTCTATATGG & floR & $58^{\circ} \mathrm{C}$ & $800 \mathrm{bp}$ & Ahmed et al., 2007 \\
\hline StCM-R & ATGCAGAAGTAGAACGCGAC & & & & \\
\hline $\begin{array}{l}\text { Streptomycin } \\
\text { aadA-F }\end{array}$ & GTGGATGGCGGCCTGAAGCC & aadA & $60^{\circ} \mathrm{C}$ & $525 \mathrm{bp}$ & Madsen et al., 2000 \\
\hline aadA-R & AATGCCCAGTCGGCAGCG & & & & \\
\hline $\begin{array}{l}\text { strA-strB-F } \\
\text { strA-strB-R }\end{array}$ & $\begin{array}{l}\text { ATGGTGGACCCTAAAACTCT } \\
\text { CGTCTAGGATCGAGACAAAG }\end{array}$ & $\begin{array}{l}\text { strA- } \\
\text { strB }\end{array}$ & $60^{\circ} \mathrm{C}$ & 893 bp & Tamang et al., 2007 \\
\hline
\end{tabular}

\section{Results}

\subsection{Incidence of $E$. coli}

Examination of broiler chickens in different localities of Assiut and El-Minya Governorates showed typical clinical signs and post mortem lesions of colibacillosis. The results revealed that over all isolation incidences were 210 suspected $E$. coli isolates out of 300 examined samples with a percentage
$70 \%$. The incidence of the suspected $E$. coli isolates from liver in freshly dead birds was 150 out of 200 examined samples with percentage $75 \%$. The examination of living diseased birds resulted in isolation of $40 \mathrm{E}$. coli suspected samples of tracheal swabs out of 100 examined one with a percentage $40 \%$. Generally, it was observed that there was higher incidence rate obtained from liver samples collected from freshly dead birds than that collected from trachea of scarified diseased birds in both Governorates as showed in table 2 and figure 1.

Table 2. Showing incidence of the suspected E. coli isolates from liver \& trachea in Assuit and El-Minya Governorates according to the morphology and biochemical characteristics.

\begin{tabular}{lllll}
\hline Locality & Type of sample & No. of samples & No. of suspected $\boldsymbol{E}$. coli isolates & \% of suspected isolates \\
\hline \multirow{2}{*}{ Assiut } & liver & 130 & 120 & $92 \%$ \\
& Tracheal swabs & 70 & 30 & $43 \%$ \\
El-Minya & Liver & 70 & 30 & $43 \%$ \\
Total & Tracheal swabs & 30 & 10 & $33 \%$ \\
\hline
\end{tabular}

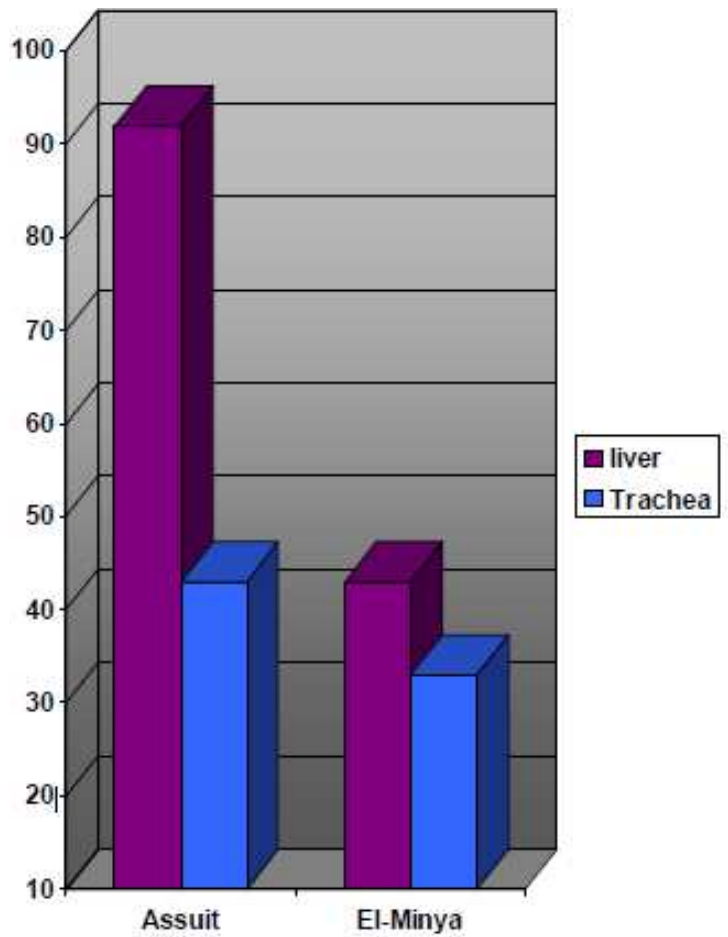

Figure 1. Showing incidence of the suspected E. coli isolates from liver and trachea in Assuit and El-Minya Governorates according to the morphology and biochemical characteristics.

\subsection{Phenotypic Identification E. coli Isolates}

Table 3. Biochemical characters of the suspected E. coli isolates.

\begin{tabular}{ll}
\hline Biochemical test & Result \\
\hline Indole & + \\
Methyl red & + \\
Voges Proskauer & - \\
Citrate utilization & - \\
Urease & - \\
$\mathrm{H}_{2}$ S production & - \\
Nitrate reduction & + \\
Gelatine liquefaction & - \\
Arginine dihydrolase & V \\
Sugar fermentation & \\
Lactose & + \\
Sucrose & V \\
Dulcitol & V \\
Salicin & V \\
Arabinose & + \\
Inositol & - \\
Xylose & V \\
\hline
\end{tabular}

$\mathrm{V}=$ variable

The growth of suspected $E$. coli on eosin methylene blue (EMB) agar, appeared as dark green-black colonies with metallic sheen. Gram stained slides of suspected colonies showed gram negative medium sized bacilli (single short to long slender rods). Single suspected E. coli colonies were 
inoculated into semi-solid media, and results revealed that the appearance of inverted tree at site of stabbing (motile bacteria). The suspected $E$. coli colonies were biochemically identified as described in table 3 .

\subsection{Serological Identification of E. coli Suspected Isolates}

As summarized in table 4, twenty-six typable E. coli isolates $(86.6 \%)$ and four isolates were negative $(13.3 \%)$ from a total thirty isolates were serotyped. Among the typable isolates, $23 \%$ of isolates belonged to the $\mathrm{O}_{78}$ serogroup, $15.38 \%$ of isolates belonged to $\mathrm{O}_{2}$ serogroup, $11.5 \%$ of isolates belonged to the $\mathrm{O}_{91}$ serotype, also $11.5 \%$ of isolates belonged to $\mathrm{O}_{1}$ serotype and $7.69 \%$ of isolates belonged to serotypes $\mathrm{O}_{127}, \mathrm{O}_{146}$, while the percentage of isolation was $3.84 \%$ for each of $\mathrm{O}_{114}, \mathrm{O}_{121}, \mathrm{O}_{44}$, $\mathrm{O}_{163}, \mathrm{O}_{26}, \mathrm{O}_{124}$, serotypes.

Table 4. Showing results of serotyping of 30 of E. coli isolates.

\begin{tabular}{|c|c|c|c|c|}
\hline Locality & Serodiagnosis & Type of sample & NO. of isolates & $\%$ of strain \\
\hline \multirow{13}{*}{ Assiut } & $\mathrm{O}_{146}$ & Liver & 2 & $8 \%$ \\
\hline & $\mathrm{O}_{78}$ & Liver & 5 & $20 \%$ \\
\hline & $\mathrm{O}_{26}$ & Trachea & 1 & $4 \%$ \\
\hline & $\mathrm{O}_{2}$ & Liver & 3 & $12 \%$ \\
\hline & $\mathrm{O}_{91}$ & Trachea & 1 & $4 \%$ \\
\hline & $\mathrm{O}_{114}$ & Liver & 1 & $4 \%$ \\
\hline & $\mathrm{O}_{121}$ & Trachea & 1 & $4 \%$ \\
\hline & $\mathrm{O}_{127}$ & Liver & 1 & $4 \%$ \\
\hline & $\mathrm{O}_{1}$ & Liver & 3 & $12 \%$ \\
\hline & $\mathrm{O}_{44}$ & Liver & 1 & $4 \%$ \\
\hline & $\mathrm{O}_{124}$ & Liver & 1 & $4 \%$ \\
\hline & $\mathrm{O}_{163}$ & Liver & 1 & $4 \%$ \\
\hline & $-\mathrm{ve}$ & Liver & 4 & $16 \%$ \\
\hline \multirow[t]{2}{*}{ Total } & & & 25 & \\
\hline & $\mathrm{O}_{91}$ & Liver & 2 & $40 \%$ \\
\hline \multirow{3}{*}{ El-Minya } & $\mathrm{O}_{2}$ & Liver & 1 & $20 \%$ \\
\hline & $\mathrm{O}_{127}$ & Liver & 1 & $20 \%$ \\
\hline & $\mathrm{O}_{78}$ & Trachea & 1 & $20 \%$ \\
\hline Total & & & 5 & \\
\hline
\end{tabular}

\subsection{Determination of Antimicrobial Susceptibility and Resistance Patterns of E. coli Isolates Using Standard Disk Diffusion} Method

Results revealed that all isolates were sensitive to doxycycline then to gentamycin and norfloxacin with different percentages, while the highest percentage of resistance to cefradine, spectinomycin, amoxicillin, colistin sulfate and streptomycin respectively, results were summarized in table 5 .

Table 5. Results of antibacterial sensitivity test of E. coli isolates $(n=12)$ by disk diffusion method.

\begin{tabular}{|c|c|c|c|c|c|c|}
\hline \multirow{2}{*}{ Antibacterial agent } & \multicolumn{3}{|c|}{ Interpretation of zone diameter (mm) } & \multicolumn{3}{|l|}{ Results } \\
\hline & Resistant & Intermediate & Sensitive & Resistant \% & Intermediate \% & Sensitive \% \\
\hline Colistin-sulfate (CT) & $\leq 8$ & $9-10$ & $\geq 11$ & 50 & 17 & 13 \\
\hline Doxycycline (DO) & $\leq 13$ & $14-17$ & $\geq 18$ & 0 & 0 & 100 \\
\hline Streptomycin (S) & $\leq 11$ & $12-14$ & $\geq 15$ & 51 & 8 & 41 \\
\hline Gentamycin $(\mathrm{CN})$ & $\leq 14$ & $15-18$ & $\geq 19$ & 16 & 8 & 76 \\
\hline Norfloxacin (NOR) & $\leq 22$ & $23-27$ & $\geq 28$ & 8 & 25 & 67 \\
\hline Cefradine (CE) & $\leq 11$ & - & $\geq 12$ & 66 & 0 & 34 \\
\hline Amoxycillin (AML) & $\leq 13$ & $14-17$ & $\geq 18$ & 57 & 0 & 25 \\
\hline
\end{tabular}

\subsection{Determination of Antimicrobial Susceptibility and Resistance Patterns of E. coli Isolates Using MIC}

Results of antibacterial susceptibility and resistance patterns for 7 different antibacterial drugs using MIC were summarized in tables 6 and 7. Results showed that all isolates were sensitive to gentamycin, 11 out of 12 isolates were sensitive to doxycycline, norfloxacin, Ceftriaxone. While the highest rate of resistance was to florfenicol where the number of resistant isolates was 11 isolates out of total of 12 tested $E$. coli isolates, also number of resistant strains to streptomycin was 10 isolates out of total number of isolates.
Table 6. Results of antibacterial susceptibility and resistance patterns $12 \mathrm{E}$. coli isolates using MIC test.

\begin{tabular}{lllllllll}
\hline $\mathbf{N}$ & Strains & $\mathbf{C T}$ & $\mathbf{D O}$ & $\mathbf{S}$ & $\mathbf{C N}$ & $\mathbf{N O R}$ & $\mathbf{C E}$ & FLOR \\
\hline 1 & $\mathrm{O}_{146}$ & $\mathrm{~S}$ & $\mathrm{~S}$ & $\mathrm{R}$ & $\mathrm{S}$ & $\mathrm{S}$ & $\mathrm{S}$ & $\mathrm{R}$ \\
2 & $\mathrm{O}_{78}$ & $\mathrm{~S}$ & $\mathrm{~S}$ & $\mathrm{R}$ & $\mathrm{S}$ & $\mathrm{S}$ & $\mathrm{S}$ & $\mathrm{R}$ \\
3 & $\mathrm{O}_{26}$ & $\mathrm{~S}$ & $\mathrm{~S}$ & $\mathrm{~S}$ & $\mathrm{~S}$ & $\mathrm{~S}$ & $\mathrm{~S}$ & $\mathrm{R}$ \\
4 & $\mathrm{O}_{2}$ & $\mathrm{~S}$ & $\mathrm{~S}$ & $\mathrm{~S}$ & $\mathrm{~S}$ & $\mathrm{~S}$ & $\mathrm{~S}$ & $\mathrm{~S}$ \\
5 & $\mathrm{O}_{91}$ & $\mathrm{~S}$ & $\mathrm{~S}$ & $\mathrm{R}$ & $\mathrm{S}$ & $\mathrm{S}$ & $\mathrm{S}$ & $\mathrm{R}$ \\
6 & $\mathrm{O}_{114}$ & $\mathrm{R}$ & $\mathrm{S}$ & $\mathrm{R}$ & $\mathrm{S}$ & $\mathrm{S}$ & $\mathrm{S}$ & $\mathrm{R}$ \\
7 & $\mathrm{O}_{121}$ & $\mathrm{R}$ & $\mathrm{S}$ & $\mathrm{R}$ & $\mathrm{S}$ & $\mathrm{S}$ & $\mathrm{S}$ & $\mathrm{R}$ \\
8 & $\mathrm{O}_{127}$ & $\mathrm{R}$ & $\mathrm{S}$ & $\mathrm{R}$ & $\mathrm{S}$ & $\mathrm{S}$ & $\mathrm{S}$ & $\mathrm{R}$ \\
9 & $\mathrm{O}_{1}$ & $\mathrm{~S}$ & $\mathrm{~S}$ & $\mathrm{R}$ & $\mathrm{S}$ & $\mathrm{R}$ & $\mathrm{S}$ & $\mathrm{R}$ \\
10 & $\mathrm{O}_{44}$ & $\mathrm{~S}$ & $\mathrm{~S}$ & $\mathrm{R}$ & $\mathrm{S}$ & $\mathrm{S}$ & $\mathrm{R}$ & $\mathrm{R}$ \\
\hline
\end{tabular}




\begin{tabular}{lllllllll}
\hline $\mathbf{N}$ & Strains & CT & DO & S & CN & NOR & CE & FLOR \\
\hline 11 & $\mathrm{O}_{124}$ & $\mathrm{~S}$ & $\mathrm{~S}$ & $\mathrm{R}$ & $\mathrm{S}$ & $\mathrm{S}$ & $\mathrm{S}$ & $\mathrm{R}$ \\
12 & $\mathrm{O}_{163}$ & $\mathrm{~S}$ & $\mathrm{I}$ & $\mathrm{R}$ & $\mathrm{S}$ & $\mathrm{S}$ & $\mathrm{S}$ & $\mathrm{R}$ \\
\hline
\end{tabular}

$\mathrm{N}$ : no of isolates, S: Sensitive, I: Intermediate, R: Resistant, CT: Colistin sulphate, DO: Doxycycline, S: Streptomycin, CN: Gentamycin, NOR: Norfloxacin, CE: Ceftriaxone, FLOR: Florfenicol

Table 7. Showing MIC percentage of resistance, sensitivity of E. coli isolates against 7 selected antimicrobial agents.

\begin{tabular}{llll}
\hline \multirow{2}{*}{ Antibacterial agent } & MIC & & \\
\cline { 2 - 4 } & Sensitive & Intermediate & Resistant \\
\hline Colistin sulfate & $75 \%$ & $0 \%$ & $25 \%$ \\
Doxycycline & $91.6 \%$ & $8.3 \%$ & $0 \%$ \\
Streptomycin & $16 \%$ & $0 \%$ & $84 \%$ \\
Gentamycin & $100 \%$ & $0 \%$ & $0 \%$ \\
Norfloxacin & $91.6 \%$ & $0 \%$ & $8.3 \%$ \\
Ceftriaxone & $91.6 \%$ & $0 \%$ & $8.3 \%$ \\
Florfenicol & $8.3 \%$ & $0 \%$ & $91.6 \%$ \\
\hline
\end{tabular}

\subsection{Detection of Antimicrobial Resistance Genes of E. coli Isolates}

Detection of antibacterial resistance genes in 12 serologically identified $E$. coli isolates showed that $f$ loR gene (Florfenicol resistance gene) was detected in 6 isolates and strA-strB gene was detected in 5 isolates, while aadA gene was detected in all 12 isolates. both strA-strB and aadA are streptomycin resistance gene. Results were summarized in tables 8 and figures 2, 3, 4 .

Table 8. Showing results of detection of E. Coli resistance genes in isolates.

\begin{tabular}{lllll}
\hline $\mathbf{N}$ & Strains & floR & aadA & strA-strB \\
\hline 1 & $\mathrm{O}_{146}$ & - & + & + \\
2 & $\mathrm{O}_{78}$ & - & + & - \\
3 & $\mathrm{O}_{26}$ & + & + & - \\
4 & $\mathrm{O}_{2}$ & + & + & + \\
5 & $\mathrm{O}_{91}$ & - & + & + \\
6 & $\mathrm{O}_{114}$ & - & + & + \\
7 & $\mathrm{O}_{121}$ & - & + & - \\
8 & $\mathrm{O}_{127}$ & + & + & - \\
9 & $\mathrm{O}_{1}$ & + & + & - \\
10 & $\mathrm{O}_{44}$ & - & + & - \\
11 & $\mathrm{O}_{124}$ & + & + & - \\
12 & $\mathrm{O}_{163}$ & + & + & + \\
Total & & $54.5 \%$ & $100 \%$ & $41.66 \%$ \\
\hline
\end{tabular}

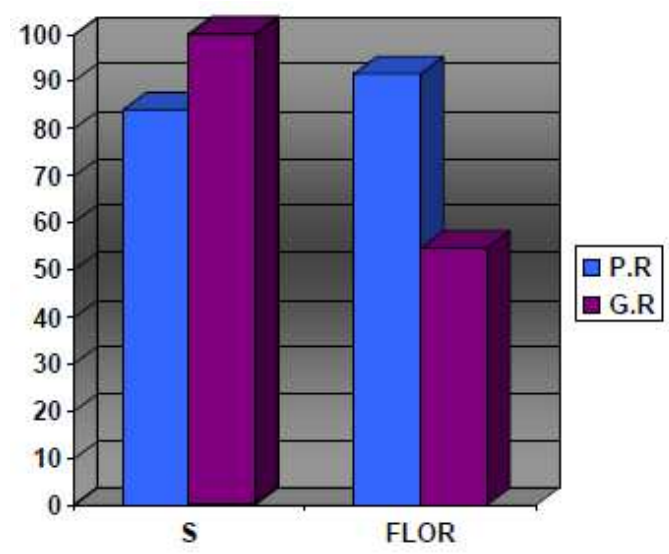

Figure 2. Comparison between phenotypic and genotypic resistance percentages.

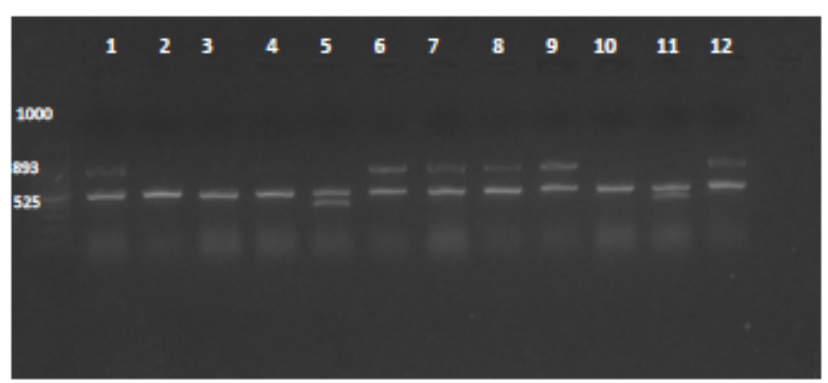

Figure 3. All samples produce band at $525 \mathrm{bp}$ (positive to aadA gene) while strA-strB gene was detected in 6 samples which produce band at $893 \mathrm{bp}$ in lane 2, 6, 7, 8, 9, 12. Lane M: 1Kb DNA Ladder.

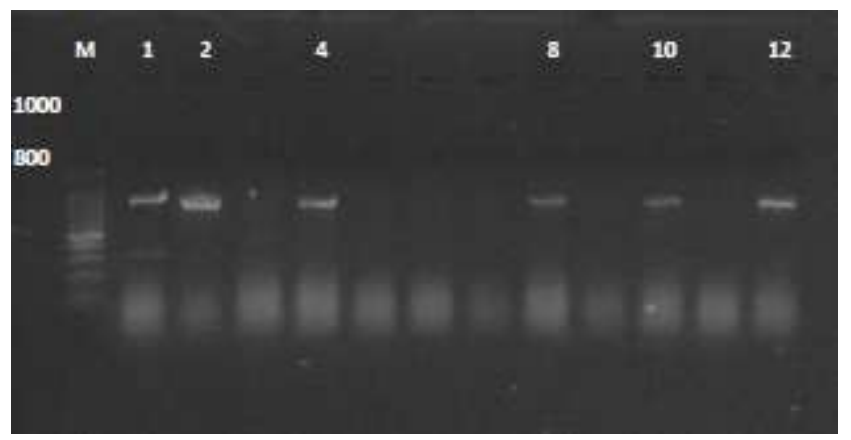

Figure 4. Detection of flor gene in 6 samples producing band at 800bp in lane 1, 2, 4, 8, 10, 12. Lane M: $1 \mathrm{~Kb}$ DNA Ladder.

\section{Discussion}

The current study aimed to detect the occurrence of $E$. coli from different localities of Upper Egypt as well as to investigate antibiotic resistance, that was done by collection of liver and tracheal swabs from diseased broiler chicken flocks, all flocks were suspected to be infected with colibacillosis and the main clinical manifestations were depression, ruffled feathers, huddling together, loss of appetite, retardation of growth, respiratory distress, white pasty diarrhea, these finding were also recorded by several authors; Kumar et al., 1988 [54] and Moltarana et al., 1993 [68]. The main post-mortem findings were pericarditis, peritonitis, perihepatitis, enteritis, congestion in internal organs, petechial hemorrhages on parenchymatous organs, and air sacs varied from slight turbidity and thickness to severe muco- or fibrinopurulent inflammation, air-sacculitis and omphalitis, similar post mortem findings were described by Sojka, 1965 [80]; Awaad, 1972 [10]; Awad 1973 [11]; Bahy, 1985 [12] and Barnes and Gross, 1997 [14].

By studying isolated E. coli strains, the micro-organism was Gram negative rods, lactose fermenter on Eosin - methylene Blue (EMB) agar. The biochemical identification of isolates showed that all isolates were catalase positive, oxidase negative, also they were positive to indole, methyl red tests and negative for Voges Proskauer, urease, $\mathrm{H}_{2} \mathrm{~S}$ production and citrate utilization. They ferment glucose, lactose, sorbitol and mannitol, but sucrose fermentation was variable. These characters were in conformity with Cruickshank et al., 1975 [25]; Ewing, 1986 [30] and MacFaddin, 2000 [59].

Our results revealed that over all isolation incidences 
according to morphology and biochemical characteristics was 210 suspected $E$. coli isolates out of 300 examined samples with a percentage $70 \%$. The incidence of $E$. coli isolates from liver in dead birds was 150 suspected E. coli samples out of 200 examined samples. The examination of tracheal swabs from living diseased birds resulted in isolation of 40 suspected E. coli samples out of 100 examined one with a percentage $40 \%$. Isolation of $E$. coli from the liver had been reported by Modestas et al. [67], 2010. It was found that E. coli caused respiratory infections in poultry and could be recovered from the trachea [40].

Serotyping is the basic method for typing of E. coli strains. In the present study the results showed that, twenty-six typeable E. coli isolates [86.6\% (26/30)] and four isolates were negative $[13.3 \%(4 / 30)]$ from a total thirty isolates that have been serotyped. Among the typeable isolates, $23 \%$ of isolates belonged to the $\mathrm{O} 78$ serogroup, $15.38 \%$ of isolates belonged to $\mathrm{O} 2$ serogroup, $11.5 \%$ of isolates belonged to the O91 serotype, also $11.5 \%$ of isolates belonged to O1 serotype and $7.69 \%$ of isolates belonged to serotypes 0127,0146 , while the percentage of isolation was $3.84 \%$ for each of $\mathrm{O} 114$, O121, O44, O163, O26, O124 serotypes, and our results were consistent with a study in which serotypes $\mathrm{O} 1, \mathrm{O} 2$ and $\mathrm{O} 78$ were present in $15 \%$ to $61 \%$ of colibacillosis clinical cases [26]. Other studies reported that these serogroups are commonly associated with avian colibacillosis on a worldwide scale and confirmed their role as particularly adapted pathogens that permit involvement in extra intestinal infections [29, 46, 56, 64, 75].

Presently, antimicrobial therapy is one of the primary control measures for reducing morbidity and mortality due to APEC associated avian colibacillosis [7, 26, 35, 84]. The majority of $E$. coli isolates tested in this study for detection of phenotypic pattern of sensitivity and resistance by standard disk diffusion method, demonstrating $66 \%$ resistance to cefradine, $58 \%$ to spectinomycin, $57 \%$ to amoxicillin, $51 \%$ to streptomycin, and $50 \%$ to colistin-sulfate, nearly similar phenotypic resistance have been detected in APEC strains isolated from diseased chickens with colibacillosis in United States [44, 89], Korea [47, 50], Iran [86], China [85, 87], United Kingdom [77], Australia [72], Egypt [4], while 76\% of the isolates were sensitive to gentamycin and this finding is in agreement with a study, in which the prevalence of antimicrobial sensitivity for gentamicin was $71.2 \%$ in $E$. coli isolates from broilers with colibacillosis in Morocco [41], but this percentage is lower than a percentage reported in a study, which found that $97 \%$ of the environmental strains of $E$. coli were sensitive to gentamicin [6], and higher than the sensitivity rates that detected in other studies carried out and reported that sensitivity rates of APEC to gentamicin were $60 \%$ [1] and 64\% [19]. Resistance to gentamicin was recorded among fifty-five $E$. coli isolates from poultry meat in Tunisia and results revealed that with $2 \%$ of isolates were resistant [81]. All isolates in our study were sensitive to doxycycline by disk diffusion method with percentage $100 \%$, while results in the studies carried out by other authors, showed high rates of sensitivity to doxycycline by percentage of $52 \%$ [19], $53.75 \%$
[39], 58\% [78] and 70.12\% [88], indicating that this drug didn't used widely in the localities of samples collection, also this may reflect different patterns of antimicrobial use in different regions. Also, $67 \%$ of our isolates were sensitive to norfloxacin this result nearly similar to that detected by a study in which sensitivity to norfloxacin Chansiripornchai et al., 1995, which was 70.65\% [19].

According to results of MIC test, $84 \%$ of $E$. coli isolates tested in this study were resistant to streptomycin, this resistance levels is nearly like many previous studies $[2,27$, $31,33,72,89]$. In our research, results of MIC indicated that $91.6 \%$ of $E$. coli isolates were resistant to florfenicol while, another study in china reported $29 \%$ resistance in $E$. coli isolates from chicken [57]. In the United States, it was demonstrated that a low percentage $(4 \%)$ of avian $E$. coli isolates already display resistance to florfenicol, although the drug is not used therapeutically in chickens [48]. E. coli isolated from the faeces of intensively farmed and free-range poultry in Australia, in which small number of isolates were resistant to florfenicol by a percentage $2 \%$, as florfenicol is not registered for use in poultry in Australia [72].

Although our study revealed high level of phenotypic resistance to streptomycin and florfenicol using MIC test, but also it revealed high level of sensitivity to gentamicin, doxycycline, norfloxacin, Ceftriaxone and Colistin sulphate, with sensitivity rates of $100 \%, 91.67 \%, 91 \%, 91 \%$, and $75 \%$ respectively, these results nearly similar to a study in Germany, in which the antimicrobial resistance of $E$. coli strains isolated during 1999-2001 from cattle, swine and poultry was detected [37]. It was detected that the percentage of resistance of APEC isolates to Ceftriaxone was $3 \%$ [89]. It was revealed that resistance of $E$. coli isolates to Ceftriaxone and gentamicin, was $0 \%$ for both antibiotics [73]. The resistance of E. coli isolates from animal origin to colistin was detected, and results reported that $9.6 \%$ of isolates were resistant [18], while in another study, resistance of $E$. coli isolates to colistin was $6.3 \%$ [69]. The low level of resistance to these classes of antibiotics in broilers was not surprising possibly due to different antibiotic practices in the different countries. The results obtained in this study confirm that the disk diffusion method is not the recommended test to monitor resistance as the meaning of MIC value itself is interpreted against published standards yielding a qualitative result of resistant, intermediate, or sensitive as well as giving the treating physician and/or veterinarian quantitative data on the degree of resistance or sensitivity allowing them to optimize therapy. In contrast, the disc diffusion method is a strictly qualitative method and does not provide quantitative data [45, 61].

Variation in results of antibacterial susceptibility and resistance patterns of $E$. coli may due to several factors, from which method used for determination, types of antibacterial drugs used, and types and doses of prophylactic antibacterial drug used in poultry farms.

The results of genotypic resistance for detection of resistance genes of streptomycin and florfenicol demonstrated that the two genes responsible for resistance of streptomycin (aadA gene and strA-strB gene) were presented 
by rate of $100 \%$ and $41.66 \%$ respectively in E. coli isolates, and this genotypic pattern is similar to the observed pattern of phenotypic resistance of E. coli isolates detected with $\mathrm{MIC}$, and these results were consistent with many other authors $[2,5,36,50,58,72,87]$. The floR gene that responsible for resistance of florfenicol presented at $54.5 \%$ $(6 / 11)$ of the isolates, while the observed pattern of phenotypic resistance, of E. coli isolates detected with MIC to florfenicol was $91.66 \%$. Florfenicol resistance gene (floR) could be detected in $17.8 \%$ of the tested APEC isolates [5]. the floR gene was previously identified in $4.5 \%$ of APEC isolates from broiler chickens in Canada [17]. The variation between the phenotypic and genotypic results of florfenicol is due to several causes, from which; The floR gene is located either in the chromosomal DNA [24, 28, 32] or on a plasmid [48, 49, 84]; two types of mobile elements, both of which are widespread among Enterobacteriaceae, may be considered to carry the floR gene; gene cassettes/integrons or transposons. Although the floR gene is located between two integrons structures in the chromosomal multi-resistance gene clusters present in several Salmonella serovars [66], analysis of the sequences flanking floR in all floR-associated database entries did not reveal any sequences that suggested direct involvement of gene cassettes/integrons in the spread of floR. Therefore, the location of this gene on a transposable element appeared to be a likely explanation for its various positions on plasmids or in the chromosomal DNA.

It was concluded that $E$. coli isolated from broiler chickens in different localities of upper Egypt were resistant in high rates to streptomycin and florfenicol. MIC were more recommended than disk diffusion method in mentoring antibacterial drug sensitivity and resistance patterns. Streptomycin and florfenicol resistance genes were detected in $E$. coli isolates from broiler chickens.

\section{Acknowledgements}

The authors would like to thank the staff members of laboratory of Poultry diseases, Faculty of Veterinary Medicine, Assiut university for their help and support to finish this work.

\section{References}

[1] Abd-ElTawab AA, Abd El-Aal SA, mazied EM, El-Morsy DA. Prevalence of $E$. Coli in broiler chickens in winter and summer seasons by application of PCR with its antibiogram pattern. BVMJ 2015; 29 (2): 119-128.

[2] Adelowo OO, Fagade OE, Agerso Y. Antibiotic resistance and resistance genes in Escherichia coli from poultry farms, southwest Nigeria. J Infect Dev Countr 2014; 8 (9): 1103-1012.

[3] Ahmed AM, Hussein AI, Shimamoto T. Proteus mirabilis clinical isolate harboring a new variant of Salmonella genomic island 1 containing the multiple antibiotic resistance region. J Antimicrob Chemoth 2007; 59 (2): 184-190.

[4] Ahmed AM, Shimamoto T. Molecular characterization of multidrug-resistant avian pathogenic Escherichia coli isolated from septicemic broilers. Int J Med Microbiol 2013; 303 (8): 475-483.

[5] Ahmed D, Islam MS, Begum YA, et al. Presence of enterotoxigenic Escherichia coli in biofilms formed in water containers in poor households coincides with epidemic seasons in Dhaka. J Appl Microbiol 2013; 114 (4): 1223-1229.

[6] Alam MA, Hasan S, Pazhani GP, et al. Phenotypic and molecular characteristics of Escherichia coli isolated from Aquatic Environment of Bangladesh. Microbiol Immunol 2006; 50 (5): 359-370.

[7] Altekruse SE, Elvinger F, lee KY, et al. Antimicrobial susceptibilities of Escherichia coli strains from a turkey operation. J Am Vet Med Assoc 2002; 221: 411-416.

[8] Amara A, Ziani Z, Bouzoubaa, K. Antibiotic resistance of $E$. coli strains isolated in Morocco from chickens with colibacillosis. Vet Microbiol 1995; 43: 325-330.

[9] Asai T, Hiki M, Ozawa M, et al. Control of the development and prevalence of antimicrobial resistance in bacteria of food animal origin in Japan: A new approach for risk management of antimicrobial veterinary medicinal products in Japan. Foodborne Pathog Dis 2014; 11: 171-176.

[10] Awaad MH. Studies on coli septicemia in chickens, MVSc Thesis (poultry diseases) 1972; Faculty of Veterinary Medicine, Cairo University, Egypt.

[11] Awad FI, Bassiouni AA., El-Sisi MA, Awaad MH. Studies on coli septicemia in chickens. Egy J Vet Sci 1973; 10: 85.

[12] Bahy EA. Studies on E. Coli in poultry, MVSc Thesis 1985; Faculty of Veterinary medicine, Assiut University, Egypt.

[13] Barbieri NL, Oliveira AL, Tejkowski TM, et al. Genotype and pathogenicity of cellulitis isolates reveal traits that modulate APEC virulence. PLOS 2013; 8: 72-322.

[14] Barnes H, Gross W. Colibacillosis. In: Goss, W. B. (Ed), Diseases of Poultry 1997; Iowa State University Press, Ames Iowa, 131-141.

[15] Barnes H, Nolan LK, Vaillancourt J. Colibacillosis. In: Saif YM, Fadly AM., Glisson JR, et al (eds), Diseases of poultry, $12^{\text {th }}$ ed. 2008; 691-732.

[16] Black RC. Epidemiology of traveller's diarrhea and relative importance of various pathogens. Rev Infect Dis 1990; 12: 573-579.

[17] Bonnet C, Diarrassouba F, Brousseau R, et al. Pathotype and antibiotic resistance gene distributions of Escherichia coli isolates from broiler chickens raised on antimicrobial-supplemented diets. Appl Environ Microb 2009; 69: 55-6962.

[18] Boyen F, Vangroenweghe f, Butaye P, et al. Disk prediffusion is a reliable method for testing colistin susceptibility in porcine E. coli strains, Vet Microbiol 2010; 144 (3-4): 359-362.

[19] Chansiripornchai N, Mooljuntee S, Boonkhum P. Antimicrobial Sensitivity of Avian Pathogenic Escherichia coli (APEC) Isolated from Chickens during 2007-2010. Thai J Vet Med 2011; 41 (4): 519-522.

[20] Chansiripornchai N, Pakpinyo S, Sasipreeyajan J. The in vitro antimicrobial sensitivity testing of Escherichai coli isolated from commercially reared chickens. Thai J Vet Med 1995; 25: 275-283. 
[21] Chen X, Pan W, Zhang W, et al. Quinolone resistance in Escherichia coli and Salmonella spp. isolates from diseased chickens during 1993-2008 in China. Afr J of Microbiol Res 2011; 5 (19): 3078-3083.

[22] Clinical and Laboratory Standards Institute (CLSI). Performance Standards for Antimicrobial Disk and Dilution Susceptibility Tests for Bacteria Isolated from Animals $3^{\text {rd }}$ ed. 2008; CLSI Document M31-A3. Wayne, PA.

[23] Clinical and Laboratory Standards Institute (CLSI). Performance Standards for Antimicrobial Susceptibility Testing $23^{\text {rd }}$ Informational Supplement 2013; CLSI Document M100-S23. Wayne, PA.

[24] Cloeckaert A, Sidi Boumedine K, Flaujac G. Occurrence of a Salmonella enterica serovar Typhimurium DT104-like antibiotic resistance gene cluster including the floR gene in $S$. enterica serovar Agona isolates. Antimicrob Agents Chemother 2000; 44: 1359-1361.

[25] Cruickshank R, Duguid JP, Maramion BP, Swain RHA. Medical microbiology $12^{\text {th }}$ Ed. 1975; S. living ston limited, Edinpurg and London.

[26] DhoMoulin M, Fairbrother JM. Avian pathogenic Escherichia coli (APEC). Vet Res 1999; 30 (2-3): 299-316.

[27] Diarrassouba F, Diarra MS, Bach S, et al. Antibiotic resistance and virulence genes in commensal E. coli and Salmonella isolates from commercial broiler chicken farms. J Food Prot 2007; 70: 1316-1327.

[28] Doublet B, Schwarz S, Nußbeck E. Molecular analysis of chromosomally florfenicol resistant $E$. coli isolates from France and Germany. J Antimicrob Chemother 2002; 49: 49-54.

[29] Ewers C, Janßen T, Kießling S, et al. Molecular epidemiology of avian pathogenic Escherichia coli (APEC) isolated from colisepticemia in poultry. Vet Microbiol 2004; 104 (1): 91-101.

[30] Ewing WH. Edwards and Ewing's Identification of Enterobacteriaceae $4^{\text {th }}$ ed. 1986; Elsevier, Amsterdam, 1-536.

[31] Forgetta V, Rempel H, Malouin F, et al. Pathogenic and multidrug-resistant Escherichia fergusonii from broiler chicken. Poult 2012; 91: 512-525.

[32] Frech G, Schwarz S. Plasmid-encoded tetracycline resistance in Salmonella enterica subsp. enterica serovars Choleraesuis and Typhimurium: identification of complete and truncated Tn1721 elements. FEMS Microbiol Lett 1999; 176: 97-103.

[33] Furtula V, Farrell EG, Diarrassouba F, et al. Veterinary pharmaceuticals and antibiotic resistance of Escherichia coli isolates in poultry litter from commercial farms and controlled feeding trials. Poult 2010; 89: 180-88.

[34] Ghodousi A, Bonura C, Noto AMD, Mammina C. Extended spectrum lactamase AmpC producing and fluoroquinolone resistant $E$. coli in retail broiler chicken meat, Italy. Foodborne Pathog Dis 2015; 12 (7): 619-625.

[35] Giraud E, Leroy-Setrin S, Flaujac G, et al. Characterization of high-level fluoroquinolone resistance in Escherichia coli O78: K80 isolated from turkeys. J Antimicro Chemother 2001; 47: 341-343.

[36] Green KD, Chen W, Garneau-Tsodikova S. Effects of altering aminoglycoside structures on bacterial resistance enzyme activities. Antimicrob Agents Chemother 2011; 55: 3207-3213.

[37] Guerra B, Junker E, Schroeter A, et al. Phenotypic and genotypic characterization of antimicrobial resistance in German Escherichia coli isolates from cattle, swine and poultry. J Antimicrob Agents Chemother 2003; 52: 489-492.

[38] Hassan AK, Shahata MA, Refaie EM, Ibrahim RS. Detection and Identification of Helicobacter pullorum in Poultry Species in Upper Egypt. J Adv Vet Res 2014; 4 (1): 42-48.

[39] Hassan MM, Amin KB, Ahaduzzaman M, et al. Antimicrobial resistance pattern against E. coli and Salmonella in layer poultry. Res J Vet Pract 2014; 2 (2): 30-35.

[40] Huff WE, Huff GR, Rath NC, et al. Prevention of Escherichia coli respiratory infection in broiler chickens with bacteriophage (SPR02). Poult 2002; 81: 437-441.

[41] Huiting J. Antimicrobial resistance of Escherichia coli in broilers with colibacillosis in Morocco, MSc thesis 2015; Faculty of Veterinary Medicine, Utrecht University, Morocco.

[42] Jakobsen AK, Skjøt-Rasmussen L, Ejrnæs K, et al. Escherichia coli isolates from broiler chicken meat, broiler chickens, pork, and pigs share phylogroups and antimicrobial resistance with community-dwelling humans and patients with urinary tract infection. Foodborne Pathol Dis 2010; 7 (5): 537-547.

[43] Jennifer MA. Determination of Minimum Inhibitory Concentration. J Antimicrob chemother 2001; 48 (1): 5-16.

[44] Johnson TJ, Siek KE, Johnson SJ, Nolan LK. DNA sequence and comparative genomics of pAPEC-O2-R, an avian pathogenic Escherichia coli transmissible $\mathrm{R}$ plasmid. Antimicrob Agents Chemother 2005; 49: 4681-4688.

[45] Jorgensen J, Ferraro MJ. Antibiotic susceptibility testing: A review of general principles and contemporary practices. Med Microbiol 2009; 49: 1749-1755.

[46] Kabir SML. Avian colibacillosis and salmonellosis: a closer look at epidemiology, pathogenesis, diagnosis, control and public health concerns. Int J Environ Res Public Health 2010; 7 (1): 89-114.

[47] Kang HY, Jeong YS, Oh JY, et al. Characterization of antimicrobial resistance and class 1 integrons found in $E$. coli isolates from humans and animals in Korea. J Antimicrob Chemother 2005; 55: 639-644.

[48] Keyes K, Hudson C, Maurer JJ. Detection of florfenicol resistance genes in Escherichia coli isolated from sick chickens. Antimicrob Agents Chemother 2000; 44: 421-424.

[49] Kim EH, Aoki T. Sequence analysis of the florfenicol resistance gene encoded in the transferable R-plasmid of a fish pathogen, Pasteurella piscisida. Microbiol Immunol 1996; 40: 665-669.

[50] Kim TE, Jeong YW, Cho SH, et al. Chronological study of antibiotic resistances and their relevant genes in Korean avian pathogenic Escherichia coli isolates. J Clin Microbiol 2007; 45: 3309-3315.

[51] Kok T, Worswich D, Gowans E. Some serological techniques for microbial and viral infections. In: Collee J, Fraser A, Marmion B, Simmons A (eds.), Practical Medical Microbiology $14^{\text {th }}$ ed. 1996; Edinburgh, Churchill Livingstone, UK.

[52] Koneman EW, Hullen SD, Janda W, et al. Diagnostic microbiology $5^{\text {th }}$ Ed. 1997; J. B. Lippincott Co. New York. 
[53] Kreig N, Holt J. Bergey's Manual of systemic bacteriology 1, William and Wilkins 1984; Baltimore, M. D. 21202, USA.

[54] Kumar KU, Sudhakar R, Rao PP. A note on E. Coli infection in poultry. Poult adviser 1988; 21 (6): 49-51.

[55] La Ragione RM, Narbad A, Gasson M., Woodward MJ. In vivo characterization of Lactobacillus johnsonii FI9785 for use as a defined competitive exclusion agent against bacterial pathogens in poultry. Lett Appl Microbiol 2004; 38 (3): 197-205.

[56] La Ragione RM, Woodward M. Virulence factors of Escherichia coli serotypes associated with avian colisepticaemia. Res Vet Sci 2002; 73 (1): 27-35.

[57] Li XS, Wang GQ, Du XD, et al. Antimicrobial susceptibility and molecular detection of chloramphenicol and florfenicol resistance among Escherichia coli isolates from diseased chickens. J Vet Sci 2007; 8 (3): 243-247.

[58] Li Y, Chen L, Wu X, Huo S. Molecular characterization of multidrug-resistant avian pathogenic Escherichia coli isolated from septicemic broilers. Poult Sci 2015; 94: 601-611.

[59] MacFaddin JF. Biochemical tests for identification medical bacteria 2000; Warery Press Inc, Baltimore, Md. 21202 USA.

[60] Madsen L, Aarestrup FM, Olsen JE. Characterisation of streptomycin resistance determinants in Danish isolates of Salmonella Typhimurium. Vet Microbiol 2000; 75: 73-82.

[61] Mahon C, Lehman D, Manuselis G. Textbook of diagnostic microbiology $4^{\text {th }}$ ed. 2011; Maryland Heights, Saunders Elsevier.

[62] Marshall BD, Petrowski Levy SB. Inter- and intraspecies spread of Escherichia coli in a farm environmental in the absence of antibiotic usage. Proc Natl Acad Sci U S A 1990; 87: 6609-6613.

[63] Martinez JL, Baquero F. Interactions among strategies associated with bacterial infection: pathogenicity, epidemicity, and antibiotic resistance. Clinic Microbiol 2002; 15: 647-679.

[64] McPeake S, Smyth J, Ball H. Characterization of avian pathogenic Escherichia coli (APEC) associated with colisepticaemia compared to faecal isolates from healthy birds. Vet Microbiol 2005; 110 (3): 245-253.

[65] Mellata M. Human and avian extraintestinal pathogenic E. coli: infections, zoonotic risks, and antibiotic resistance trend. Foodborne Pathog Dis 2013; 10 (11): 916-932.

[66] Meunier D, Boyd D, Mulvey MR. Salmonella enteric serotype Typhimurium DT104 antibiotic resistance genomic island 1 in serotype Paratyphi B. Emerg Infect Dis 2002; 8: 430-433.

[67] Modestas R, Rita S, Ričardas, K, et al. Prevalence and Antimicrobial Resistance of $E$. Coli isolated from chicken liver sold in retail markets. Vet Zootech-Lith 2010; 52 (74): 67- 72.

[68] Moltarana HK, Dutta NK, Missa PR. Enteritis in poultry in Orissa: in vitro drug susceptibility to different antimicrobial agents. Indian Vet J 1993; 70 (3): 281-282.

[69] Morales AS, de Araujo JF, Gomes VD, et al. Colistin Resistance in Escherichia coli and Salmonella enterica Strains Isolated from Swine in Brazil. Sci World J 2012; 109795: 4 pages. https://doi.org/10.1100/2012/109795.

[70] National Committee for Clinical Laboratory Standards
(NCCLS). Methods for dilution antimicrobial susceptibility tests for bacteria that grow aerobically. N NCCLS, Wayne, Approved Standard M7- A6. 2003.

[71] National Committee for Clinical Laboratory Standards (NCCLS). Performance Standards for Antimicrobial Disk and Dilution Susceptibility Tests for Bacteria Isolated from Animals. NCCLS, Wayne, Approved Standard M31-A2. 2003.

[72] Obeng AS, Rickard H, Ndi O, et al. Antibiotic resistance, phylogenetic grouping and virulence potential of Escherichia coli isolated from the faeces of intensively farmed and free-range poultry. Vet Microbiol 2011; 154: 305-315.

[73] Oosterik LH, Peeters L, Mutuku I, et al. Susceptibility of avian pathogenic Escherichia coli from laying hens in Belgium to antibiotics and disinfectants and integron prevalence. Avian Dis 2014; 58: 271-278.

[74] Osterblad M, Hakanen A, Manninen R, et al. A betweenspecies comparison of antimicrobial resistance in enterobacteria in fecal flora. Antimicrob Agents Chemother 2000; 44: 1479-1484.

[75] Persoons D, Callens B, Dewulf J, Haesebrouck F. Een update van colibacillose bij kippen. Flemish Vet J 2011; 80: 161-166.

[76] Quinn PJ, Carter ME, Markey, BK, Carter JR. Clinical Veterinary Microbiology 1994; Wolf, publishing Tavistock, London, 220- 242.

[77] Randall LP, Clouting C, Horton RA, et al. Prevalence of Escherichia coli carrying extended-spectrum $B$-lactamases (CTXM and TEM-52) from broiler chickens and turkeys in Great Britain between 2006 and 2009. J Antimicrob Chemother 2011; 66: 86-95.

[78] Raum E, Lietzau S, Baum VH, et al. Changes in Escherichia coli resistance patterns during and after antibiotic therapy: a longitudinal study among outpatients in Germany. Clinic Microbiol Infect 2008; 14 (1): 41 -8.

[79] Shehata ME, EL-Sherbiny GM, Mohamed AH, Shafik HM. Molecular and Phenotypic Characterization of Some Antimicrobial Resistance Genes in Escherichia coli Isolated from Human and Broiler Chickens. Int J Curr Microbiol Appl Sci 2016; 5 (12): 953-965.

[80] Sojka W. Escherichia coli infection in domestic animals and poultry. The Commonwealth Agricultural Bureaux 1965; Farnham Royal, Bucks England: 1-231.

[81] Soufi L, Abbassi MS, Saenz Y, et al. Prevalence and diversity of integrons and associated resistance genes in Escherichia coli isolates from poultry meat in Tunisia. Foodborne Pathog Dis 2009; 6: 1067-1073.

[82] Tamang MD, Oh JY, Seol SY, et al. Emergence of multidrug-resistant Salmonella enterica serovar Typhi associated with a class 1 integron carrying the $d f r A 7$ gene cassette in Nepal. Int J Antimicrob Agents 2007; 30 (4), 330-335.

[83] Von Baum H, Marre R. Antimicrobial resistance of Escherichia coli and therapeutic implications. Int $\mathrm{J}$ Med Microbiol 2005; 295: 503-511.

[84] White DG, Piddock LJ, Maurer JJ, et al. Characterization of fluoroquinolone resistance among veterinary isolates of avian Escherichia coli. Antimicrob Agents Chemother 2000; 44: 2897-2899. 
[85] Yang, H, Chen S, White DG, et al. Characterization of multiple-antimicrobial resistant Escherichia coli isolates from diseased chickens and swine in China. J Clinic Microbiol 2004; 42: 3483-3489.

[86] Zahraei ST, Salehi FB. Antibiotics susceptibility pattern of Escherichia coli strains isolated from chickens with coli septicemia in Tabriz Province, Iran. Int J Poult Sci 2006; 5 (7): 677-684.

[87] Zhang FY, Huo SY, Li YR, et al. A survey of the frequency of aminoglycoside antibiotic resistant genotypes and phenotypes in Escherichia coli in broilers with septicaemia in Hebei, China. Poult Sci 2014; 55: 305-310.

[88] Zhang T, Wang CG, Jiang GE, et al. Molecular epidemiological survey on aminoglycoside antibiotics resistant genotype and phenotype of avian Escherichia coli in North China. Poult Sci 2012; 91: 2482-2486.

[89] Zhao S, Maurer JJ, Hubert S, et al. Antimicrobial susceptibility and molecular characterization of avian pathogenic Escherichia coli isolates. Vet Microbiol 2005; 107: 215-224. 